\title{
"The impact of COVID-19 on formation and evaluation of portfolio performance: A case of Indonesia"
}

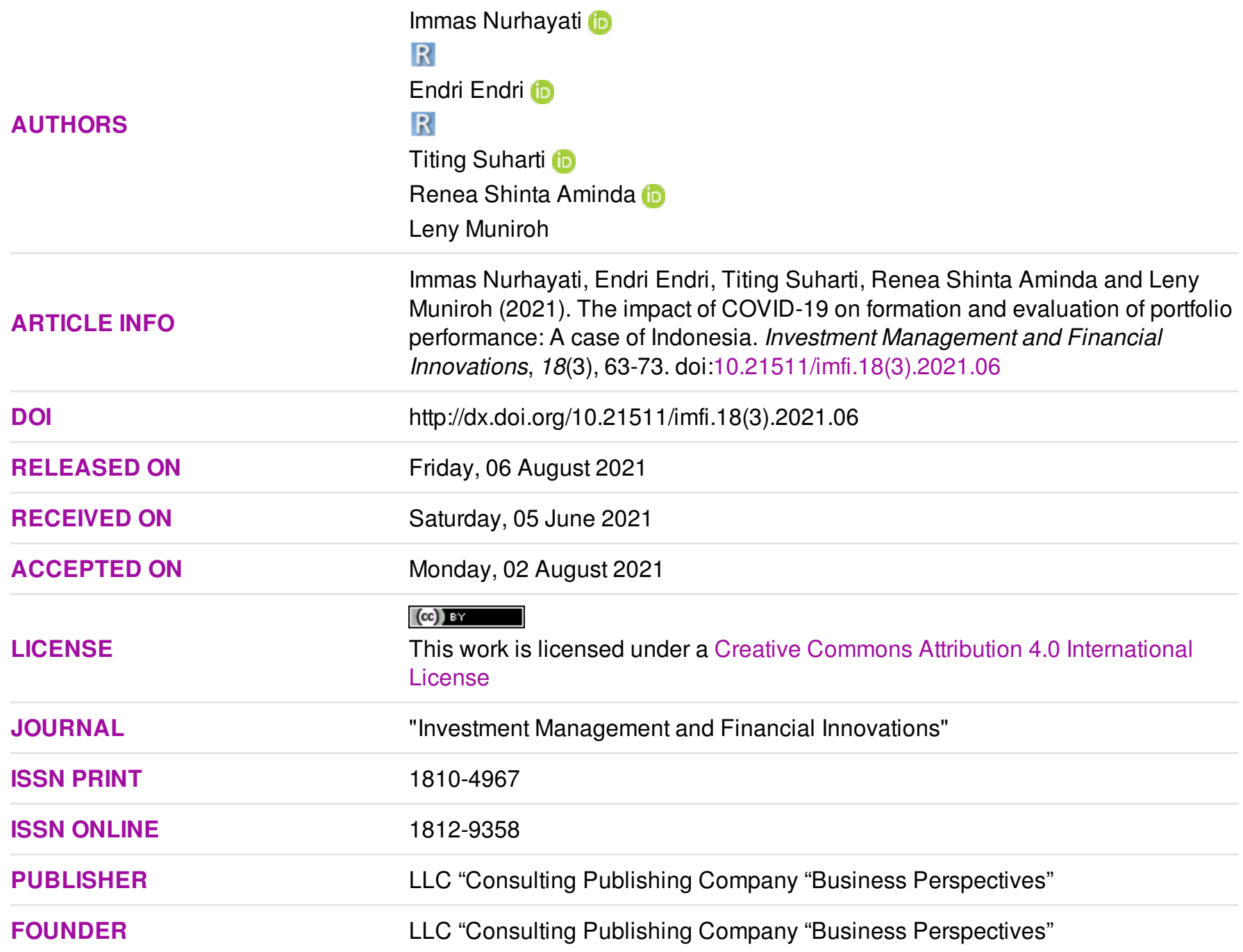

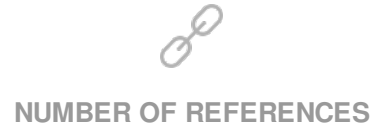

26

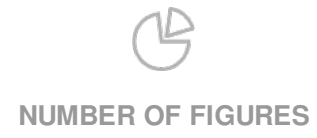

0

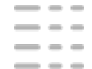

NUMBER OF TABLES

7

(C) The author(s) 2021. This publication is an open access article. 


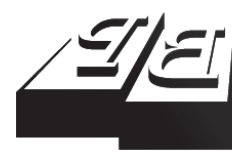

BUSINESS PERSPECTIVES

(O)

LLC "CPC "Business Perspectives" Hryhorii Skovoroda lane, 10, Sumy, 40022, Ukraine www.businessperspectives.org
Received on: $5^{\text {th }}$ of June, 2021 Accepted on: $2^{\text {nd }}$ of August, 2021 Published on: $6^{\text {th }}$ of August, 2021

(C) Immas Nurhayati, Endri Endri, Titing Suharti, Renea Shinta Aminda, Leny Muniroh, 2021

Immas Nurhayati, Associate Professor, Faculty of Economics and Business, Universitas Ibn Khaldun, Indonesia.

Endri Endri, Associate Professor, Faculty of Economics and Business, Universitas Mercu Buana, Indonesia. (Corresponding author)

Titing Suharti, Associate Professor, Faculty of Economics and Business, Universitas Ibn Khaldun, Indonesia.

Renea Shinta Aminda, Assistant Professor, Faculty of Economics and Business, Universitas Ibn Khaldun, Indonesia.

Leny Muniroh, Assistant Professor, Faculty of Economics and Business, Universitas Ibn Khaldun, Indonesia

This is an Open Access article, distributed under the terms of the Creative Commons Attribution 4.0 International license, which permits unrestricted re-use, distribution, and reproduction in any medium, provided the original work is properly cited.

Conflict of interest statement: Author(s) reported no conflict of interest

Immas Nurhayati (Indonesia), Endri Endri (Indonesia), Titing Suharti (Indonesia), Renea Shinta Aminda (Indonesia), Leny Muniroh (Indonesia)

\title{
THE IMPACT OF COVID-19 ON FORMATION AND EVALUATION OF PORTFOLIO PERFORMANCE: A CASE OF INDONESIA
}

\begin{abstract}
This paper examines how to build a portfolio and assess the impact of the COVID-19 on portfolio performance using the Sharpe single index model. The research sample consists of ten high market capitalization stocks representing five price fractions of the population listed stocks on the Indonesia Stock Exchange during the COVID-19 outbreak from March 1 to May 31, 2020. The results show that there are four stocks that are included in the portfolio formation, namely CASA with a proportion of $50 \%$, BNLI with a proportion of $26 \%$, UNVR with a proportion of $15 \%$, and HMSP with a proportion of $9 \%$. Based on portfolio performance testing using the Sharpe single in dex model, it is known that the portfolio during the COVID-19 has a negative Sharpe ratio, meaning that portfolio performance is underperforming. The findings provide evidence that COVID-19 has had a negative impact on the stock market so that many investors have suffered losses on their portfolios. The implications of findings are that investors must evaluate portfolio performance and restructure the formation of new portfolios by considering the COVID-19 pandemic outbreak as a systematic risk factor that can determine the expected returns.
\end{abstract}

\section{Keywords}

JEL Classification

\section{INTRODUCTION}

The development of the global economy shows many opportunities to invest in the capital market, which provides opportunities for international investors to benefit from obtaining higher returns with lower risk. Investment decisions depend on the amount of return and risk where with the increasing risk the expected return is greater. Stocks that have a high rate of return with certain risks and the ways to minimize that risk can be identified by conducting a portfolio analysis. Portfolio analysis will assist investors in making decisions to determine which portfolio is the most efficient, namely the portfolio with the smallest risk with a certain return or the maximum return with a certain risk. Risk cannot be eliminated but can be minimized by diversification (portfolio). An optimal portfolio can be formed related to the desire to get a certain return with minimal risk. The problem that is often faced by investors is the confusion in determining stock investments and the large proportion of funds to be invested in these stocks so that most investors choose stocks for their portfolios randomly without appropriate analytical techniques and mechanisms to underlie the formation of their portfolios. The use of the investment feasibility analysis through the formation of an optimal portfolio becomes a reference for investors to choose which portfolio is appropriate to take according to investor preferences. Therefore, this study is important to do to provide knowledge 
about analytical techniques in estimating the return and risk of stock investments that will be carried out by investors, especially during the COVID-19.

This study focuses on portfolio formation and evaluation of high-capitalization stocks by taking into account the optimal rate of return with a certain level of risk using the Sharpe single index model as the most commonly used method for the expected return risk trade-off to measure the impact of the COVID-19 on the Indonesian Stock Market (JCI) as a financial market that has also been affected by the COVID-19, as indicated by a drastic decline in the JCI. This analysis will be very useful for investors in determining and forming their stock portfolio amid situations where global investor confidence has declined and uncertainty over investment returns has increased. They have doubts and concerns that the portfolio they create cannot provide positive returns. However, under the COVID-19 pandemic and the uncertainty of market conditions, the investors should always consider the opportunities to get returns and the risks that must be faced.

\section{LITERATURE REVIEW}

\subsection{Portfolio formation and performance evaluation framework}

Markowitz (1952) has proposed the first portfolio theory. A portfolio is a collection of investment instruments owned and managed by investors. Markowitz model is a portfolio determination model that emphasizes the relationship between return and investment risk. To develop a portfolio plan, several basic statistical measurements are used, including the risk and expected returns of the portfolio and the correlation of the investment instruments selected. Diversification in the portfolio can minimize risk and increase returns. Markowitz's portfolio theory is also known as the mean and variance model, where the mean is the return, while the variance is a measure of risk. Markowitz (1952) developed an index model, which is the development of a mean-variant model that determines the optimal portfolio (efficient set) of many possible combinations. This model is based on several assumptions:

1) Every investment has an expected rate of return.

2) Investors maximize their utility.

3) The estimation of investment portfolio risk is based on the expected return variability.

4) Investment options are decided based on the expected rate of return and risk with a decreasing rate of return.
5) The portfolio that provides the highest rate of return is efficient.

Sharpe (1963) developed the Markowitz single index model that is known as the Sharpe single index model (SIM). SIM shows the relationship between the returns of each security and the market index returns and describes several steps in the formation of an optimal portfolio in a simple way when compared to the Markowitz calculation method by calculating portfolio variance and determining other variables as conditions for the formation of an optimal portfolio. It was found that SIM is the perfect model for optimal portfolio development (Marisetty, 2012).

There are several important stages in stock portfolio investment decisions, namely analyzing stocks (the market) to identify the potential risks and expected returns; forming an optimal portfolio to select stocks that are included in the portfolio; obtaining an efficient portfolio choice from various possible combinations that exist to determine the best combination that minimizes risk and maximizes expected returns; evaluating portfolio performance using SIM to determine whether the portfolio has a good performance or vice versa (Nurhayati \& Endri, 2020). There are two methods of evaluating portfolio performance, namely the conventional method and the adjusted risk. The conventional method is measured by comparing the performance of the investment portfolio to the broader market index, while the risk-adjusted performance method as the main method of evaluating portfolio performance consists of several models, including the Sharpe ratio, Jensen alpha, 
and Treynor ratio. This study only focuses on evaluating the performance of stock portfolios based on SIM.

\subsection{Empirical studies of portfolio formation using SIM}

Kamil and Wan (2004) focused on portfolio formation of ten selected stocks from Kuala Lumpur Stock Exchange (KLSE) using a single index model with daily and weekly analysis. Based on the result, it has known that 5 monthly stocks and 2 daily stocks were selected as portfolio candidates. The conclusion of this analysis is that a weekly profit rate is higher than the daily analysis.

Subashree and Bhoopal (2017) examined empirically testing the optimal portfolio formation using the SIM on several stocks listed in Nifty 50 that represent the majority of NSE's market capitalization and calculating the proportion of each stock in its portfolio. The results showed that of the 50 stocks considered for research, only 24 stocks that had an excess return to beta above the cut-off level were selected to be included in the optimal portfolio. The majority of stocks selected came from the pharmaceutical and banking sector.

Murthy (2018) studied SIM to construct an optimal portfolio of 14 stocks in NSE Nifty metal index. Based on the calculation, there are only 2 selected stocks for the portfolio formation with the maximum suggested investment of $86 \%$ in Vedanta and $14 \%$ in Tata steel. The proportion of stocks, beta, and stock variance in this portfolio may change at any time referring to changes in market conditions. Therefore, if necessary, investors can continuously and periodically evaluate and revise their stock portfolio.

Putra and Dana (2020) determined selected stocks and each proportion of fund that will be included in the optimal portfolio and compared the optimal portfolio performance between SIM and Markowitz model of LQ45 stocks in IDX for the period February 2017-January 2020. The data used is secondary data consisted of 28 purposive research samples. Using Wilcoxon-MannWhitney test, the empirical examination of the study showed that the optimal portfolio model performance using the SIM is better than the
Markowitz model, but the result is not significant.

Sholehah et al. (2020) found out selected stocks and each proportion of fund that will be included in the optimal portfolio and compared optimal portfolio performance of LQ45 stocks in IDX from 2017-2019 using a single index model and capital asset pricing model (CAPM). The purposive sample used consisted of 17 stocks with positive average returns. The result showed there are 6 stocks are included in an optimal portfolio based on SIM and based on CAPM the optimal portfolio consists of 13 stocks. The contribution of this study is that portfolio performance evaluation using both models showed a positive average index, which means all selected stocks of the portfolio are performed to be invested.

\subsection{Empirical studies of performance evaluation and hypothesis}

The ongoing COVID-19 has caused an economic downturn at the global level and affected economic growth in almost all countries. Many companies have stopped or reduced their operational activities to prevent the spread of the virus and laidoff workers as the impact of the decline in company cash flow due to a decrease in sales (Endri et al., 2020b). The risk of global financial markets increased drastically during the COVID-19 period. The market reacted negatively to the development of positive confirmed cases due to COVID-19, which resulted in a decline in market returns (Ashraf, 2020; Al-Awadhi et al., 2020; Khan et al., 2020).

Portfolio formation and evaluating portfolio performance in the COVID-19 pandemic situation is not an easy thing. The markets are unstable, unpredictable, and there is uncertainty about investment returns. This situation resulted in the weakening of the performance of the capital market that had an impact on the negative stock portfolio performance.

Alexakis et al. (2007) used a dynamic approach for the evaluation of portfolio performance under risk conditions and examined the best strategy that investors should take in dealing with stock portfolios in times of crisis. Based on the stress test approach and simulation techniques, this study rec- 
ommends that optimal composition is obtained by comparing portfolios based on their market capitalization. Stocks with medium risk can remain in the original position but stocks with low and high risk have to adjust to survive in the crisis.

The purpose of this study is not only to make a portfolio formation but also to evaluate the performance of the portfolio in the COVID-19 pandemic. In terms of evaluating portfolio performance, there are three analytical models used, namely Sharpe single index model, Treynor alpha, and Jensen alpha ratios, but this study will only use the Sharpe index model. Some of the reasons for this are that a single index model is a model whose calculations are quite simple and very useful with relatively the same results as other models.

An empirical study that analyzes risk-adjusted performance on LQ 45 stocks on the IDX using the three models found no difference between the techniques test (Suryani \& Herianti, 2015). Suryadi et al. (2021) used the Sharpe ratio method to compare the performance of conventional and Islamic stock portfolios and found that the performance of Islamic stocks was better than conventional stocks. The study conducted by Zakarias and Tumewu (2015) concludes that the three models used by the SIM, Jensen alpha, and Treynor alpha can be used together because they can provide good information to decision-makers in the company.

Nurhayati et al. (2021a) studied the evaluation of the performance of high market capitalization stocks on the IDX during the COVID-19 using the risk-adjusted return method consisting of Jensen alpha, Treynor alpha, and Sharpe single index ratios. It was shown that in general the stocks listed on the Indonesia stock exchange was underperformed, even though these stocks is a blue-chip stock that during pre-pandemic times may have performed better. However, during times of economic recession, such as today, the level of risk that will be faced in investing is very high, especially systematic risk or market risk, namely the risk caused by global conditions.

The main objective of the study was to examine the impact of the COVID-19 event on portfolio performance using the Sharpe single index mod- el on the Indonesian stock market. Most previous research has focused on the impact of the COVID-19 on the stock market by proxying individual stock prices and indexes. There are not many studies that specifically examine the impact of the COVID-19 pandemic outbreak on the formation and evaluation of portfolio performance. This study uses the COVID-19 as a systematic risk factor in Sharpe single index model in determining the expected return on portfolios and evaluating portfolio performance during the pandemic. Based on the literature review, several hypotheses that can be built are as follows:

Hol: There is a negative difference between market returns before and after the COVID-19 pandemic.

Ha1: There is no negative difference between market returns before and after the COVID-19 pandemic.

Ho2: Portfolios selected using Sharpe single index model are underperforming.

\section{Ha2: Portfolios selected using Sharpe single index model are not underperforming.}

\section{METHODOLOGY}

To build upon the optimal portfolio, the purposive sampling was picked up from ten companies from various types of industries, which have high market capitalization and represent five fractions of a price from the population of listed stocks during the study period from March 1, 2020, to May 31, 2020. The best proportion possible can diversify the risk and maximizing the return from the selected set of companies. To test several determinants of the optimal portfolio, daily data from February 28, 2020, to May 29, 2020, are used. The samples include firms listed on IDX sorted by capitalization, which represents the biggest of each tick size, 59 daily data of stock price, IDX Composite Index, and the risk-free rate were run.

During the pandemic, to minimize the risk of loss, leading stocks are the right investment choice because the risks are relatively smaller, besides that they are also a collection of company stocks with 
good performance. Although the blue-chip issuer was affected by the pandemic, it will recover faster. The size and stability of the company can be seen from the company's capital and assets, as well as its market capitalization. Market capitalization is the price of a company's shares listed on the stock exchange, multiplied by the number of shares outstanding on the market third-tier shares with a market capitalization of Rp 500 billion and below. Second-tier shares with a market capitalization value of $\mathrm{Rp} 500$ billion to $\mathrm{Rp} 10$ trillion and shares with a market capitalization above Rp 10 trillion are referred to as first-tier shares. Stocks with all categories have the potential to earn profits; however, leading stocks in terms of risk are more profitable than other stock groups because the risk of fluctuations in value is lower. Second- or third-tier stocks are sometimes more profitable, and under certain conditions, the second-tier stock's valuation increases dramatically. The price per share of the first layer is higher than the price of the second and third layer shares. Therefore, investing in leading stocks requires a very large amount of capital (Nurhayati et al., 2021b)

The research method that can be used for portfolio formation and portfolio performance evaluation is the SIM as a technique for measuring the return and risk of a portfolio (Mahmud, 2019). This model assumes stock return movements are solely determined by changes that occur in the market. The SIM equation shows that depending on two components determined by the market expressed by the market beta and the component determined by non-market factors or individual factors. The SIM divides the rate of return of security into two parts, namely the unique component of return represented by $\alpha_{i}$ that is independent of market returns, and the component of return associated with market returns represented by $\beta_{i}, R_{m}$ The Sharpe index model measures how sensitive a stock return is to the market return (Kamil \& Wan, 2004). The combination of stock options that are included in the portfolio is based on a high-profit and low-risk bag selection. To measure portfolio performance, it can be measured by looking at the difference between the average portfolio profit rate and the risk-free interest rate (portfolio risk premium) and the total portfolio risk expressed with a standard deviation (Endri et al., 2020a).
The formation of the portfolio begins with calculating stock returns $i\left(R_{i}\right)$, expected stock returns $i$ $\left(E\left(R_{i}\right)\right)$, stock variances $\left(\sigma_{i}^{2}\right)$, market returns $\left(R_{m}, t\right)$, market expectations returns. $E\left(R_{m}\right)$ and market return variance $\left(\sigma_{m}^{2}\right)$. These variables are needed in determining covariance and beta. A security's beta $\left(\beta_{i}\right)$ represents a measure of the fluctuation between stock and market returns. If market returns are affected by the market risk, beta is a measure of a stock's risk of volatility relative to the market risk. Beta is formulated by dividing the covariance between stock and market returns by the market risk.

The stock will be chosen to be one of the candidates of the optimal portfolio is the one that will fill the criteria of excess return and beta $(E R B)>$ $C^{*}$, whereas $C^{*}$ (cut-off point) is a limit of acceptance for each stock in the portfolio. $C^{\star}$ is obtained from the big value of $C_{i}$ (Lee et al., 2018). ERB measures the excess return $\left(E\left(R_{i}\right)-R_{f}\right)$ relative to a unit of risk that cannot be diversified by beta $\left(\beta_{i}\right)$. Formula 1 calculates the cut-off rate $\left(C_{i}\right)$.

$$
C_{i}=\frac{\sigma_{m}^{2} \sum_{j=1}^{i} A_{i}}{1+\sigma_{m}^{2} \sum_{j=1}^{i} B_{i}} .
$$

The values of $A_{i}$ and $B_{i}$ for securities $i$ are determined using formulas 2 and 3.

$$
\begin{aligned}
& A_{i}=\frac{\left[E\left(R_{i}\right)-R_{f}\right] \beta_{i}}{\sigma_{e i}^{2}}, \\
& B_{i}=\frac{\beta_{i}^{2}}{\sigma_{e i}^{2}},
\end{aligned}
$$

where $\sigma_{e i}{ }^{2}$ - variance of security's residual error that is also a unique risk or an unsystematic risk.

The model for an expected return of portfolio $E\left(R_{p}\right)$ and portfolio variances $\left(\sigma_{p}\right)$ can be written as formulas 4 and 5 .

$$
\begin{aligned}
& E\left(R_{p}\right)=\alpha_{p}+\beta_{p} E\left(R_{m}\right), \\
& \sigma_{p}^{2}=\beta_{p}^{2} \sigma_{m}^{2}+\left(\sum_{i=1}^{n} w_{i}^{2} \sigma_{e i}^{2}\right),
\end{aligned}
$$


where

$$
\begin{gathered}
a_{p}(\text { weighted average of alpha })=\sum_{i=1}^{n} w_{i} \alpha_{i} ; \\
b_{p}(\text { weighted average of beta })=\sum_{i=1}^{n} w_{i} \beta_{i} ;
\end{gathered}
$$

$\beta_{p}{ }^{2} \sigma_{m}{ }^{2}-$ market risk; $w_{i}^{2} \sigma_{e i}{ }^{2}-$ weighted average of unsystematic risk of each firm; $w_{i}$ - the proportion of security $i$.

Finally, the model to analyze the portfolio performance is written in formula 6 (Samarakoon \& Hasan, 2005).

$$
S_{p}=\frac{R_{i}-R_{f}}{\sigma_{i}},
$$

where $R_{i}$ - expected return of securities or portfolio; $R_{f}$ - risk-free rate of return; $\sigma_{i}$ - deviation standard of return securities or portfolio.

The evaluation of stock portfolio performance using the Sharpe method is carried out by reducing the expected return of a stock or portfolio with a risk-free rate of return then divided by the standard deviation of stock or portfolio returns (Razak et al., 2020).

\section{EMPIRICAL RESULT AND DISCUSSION}

Table 1 reports the value of market returns, expected markets return, the variance of market returns, and the risk-free rate return of selected samples during the COVID-19 pandemic. Return and expected return have a negative value. This shows that in general, the performance of the capital market has experienced a negative performance, meaning that stock investments have a high level of risk and the impact of these results has decreased. A variance value of 0.00078 means low risk, which indicates that the actual rate of return and the expected rate of return of the securities are not too different. The risk-free return reference is $4.5 \%$ of the average Bank Indonesia (BI) interest rate during the COVID-19. Bank Indonesia's objective is to lower interest rates to support the increased role of banking intermediation and recovery from the domestic economic recession caused by the COVID-19. The $\mathrm{BI}$ interest rate remains at $4.5 \%$, meaning that during the COVID-19 the yield on the high-risk interest rate $\left(R_{f}\right)$ is relatively constant, on the other hand, the interest rate remains at the level $\left(R_{f}\right) 5.76 \%$ in the period before COVID-19.

Table 1. Result of calculation of market return, expected market return, return of variance of IDX composite and BI rate

\begin{tabular}{l|c}
\hline$\sum R_{m}$ & -0.11466 \\
\hline$E\left(R_{m}\right)=\sum R_{m} / n$ & -0.00198 \\
\hline$\sigma_{m}{ }^{2}$ & 0.00078 \\
\hdashline$R_{f}=\Sigma B I_{\text {rate }} / n$ & 0.045 \\
\hline
\end{tabular}

The calculation result of average securities return, expected securities return as a report at Table 3 shows that there is five stock have a positive value of the expected return $\left(E\left(R_{i}\right)\right)$ and also five stocks have a negative expected return value. The positive (negative) expected return indicates the level of profit (loss). In this COVID-19 outbreak period, even with high capitalization stock, the opportunity to get profit or loss is fifty percent. The relatively low variance of 0.00078 means that on average, stocks have a level of return and expected return that is more equal or equal to one another. It is expected that in the future it will be an increase of at least fifty percent in profits obtained by investors or vice versa. Both standard deviation and variance indicate the amount of risk of each stock. The greater the standard deviation, the greater the risk accepted.

Table 2 shows the change in returns before and after the pandemic, where the average return difference test is carried out. Based on the average difference test, where p-value $0.50862>$ alpha (5\%) and $t$ stat $<t$ critical, it can be concluded that the result is that the average difference in market returns after and before COVID-19 is not significant.

Table 2. The t-test: two-sample with equal variances

\begin{tabular}{l|c|c}
\hline Description & $\begin{array}{c}\text { Before the } \\
\text { COVID-19 pandemic }\end{array}$ & $\begin{array}{c}\text { After the COVID-19 } \\
\text { pandemic }\end{array}$ \\
\hline Mean & 0.000553 & -0.00198 \\
\hline t stat & 0.663077 & - \\
\hline P-value & 0.50862 & - \\
\hline t critical & 1.980992 & - \\
\hline
\end{tabular}


Table 3. The result of calculation of return, average return or expected return $E\left(R_{i}\right)$, return of variance, standard deviation, alpha (intercept), beta (slope), of the selected samples, unsystematic risk, $A_{i}, B_{i}, C i, E R B_{i}$

Source: Authors' elaboration.

\begin{tabular}{|c|c|c|c|c|c|c|c|c|c|c|c|}
\hline Var & FREN & LPKR & PWON & CASA & HMSP & KLBF & TLKM & BNLI & BBCA & UNVR & JKSE \\
\hline $\bar{R}$ & 0.00287 & -0.0023 & -0.0048 & $-0,0010$ & 0.00343 & 0.00362 & -0.0009 & 0.00264 & -0.0026 & .00317 & -0.0019 \\
\hline$E(R)$ & -0.0421 & -0.0052 & -0.0024 & 0.00371 & 0.00449 & 0.00019 & -0.0046 & 0.00361 & -0.0052 & 0.00577 & -0.0051 \\
\hline$\sigma_{i}^{2}$ & 0.00493 & 0.00271 & 0.00363 & 0.00079 & 0.00234 & 0.00217 & 0.00162 & 0.00113 & 0.00147 & 0.00204 & 0.00078 \\
\hline$\sigma_{i}$ & 0.07019 & 0.05208 & 0.06023 & 0.02804 & 0.04836 & 0.0465 & 0.04023 & 0.03360 & 0.03839 & 0.04512 & 0.02786 \\
\hline$\alpha$ & 0.00646 & $-1 E-05$ & -0.0016 & -0.0007 & 0.0061 & 0.00574 & 0.0143 & 0.00363 & -0.0003 & 0.00559 & 0 \\
\hline B & 1.81520 & 1.18280 & 1.5793 & 0.15351 & 1.34581 & 1.06962 & 1.21659 & 0.50021 & 1.16813 & 1.22534 & 1 \\
\hline$\sigma_{e i}^{2}$ & 0.00749 & 0.00379 & 0.00556 & 0.00080 & 0.00374 & 0.00305 & 0.00277 & 0.00132 & 0.00253 & 0.00320 & 0.00155 \\
\hline$A_{i}$ & -10.214 & -1.6269 & -0.6880 & 0.7088 & 1.61203 & 0.0675 & -2.0196 & 1.6616 & -2.4141 & 2.20553 & -3.3139 \\
\hline$B_{i}$ & 440.160 & 368.295 & 448.263 & 29.2830 & 483.586 & 374.594 & 534.840 & 189.060 & 538.529 & 468.953 & 643.86 \\
\hline$C_{i}$ & -0.0059 & -0.0009 & -0.0004 & 0.00054 & 0.0009 & $4.06 \mathrm{E}-05$ & -0.0011 & 0.00092 & -0.0013 & 0.00125 & -0.0017 \\
\hline$E R B_{i}$ & -0.0232 & -0.0044 & -0.0015 & 0.02420 & 0.00333 & 0.0002 & -0.0038 & 0.00723 & -0.0045 & 0.00470 & $-0,0051$ \\
\hline
\end{tabular}

The availability of risk-free asset returns $\left(R_{f}\right)$ value allows us to estimates excess return to the beta of the security (ERB). ERB is a measure to determine the excess return relative to one unit of risk where beta cannot diversify. The ERB also shows the relationship between excess return and risk and is related to the asset value. The excess return to beta is an important component in making an optimal portfolio with the single index method. All securities are ordered from the smallest ERB value to the largest ERB value. The security with the largest ERB value is a candidate to be included in the optimal portfolio.

Through estimates $A_{i}$ and $B_{i}$, the cut-off $\left(C_{i}\right)$ can be calculated as an important value to determine the cut-off point $\left(C^{\star}\right)$. $C^{*}$ is the biggest value of $C_{1}$ that has function as the limit and determining the op- timal portfolio candidates. Cut-off point $\left(C^{*}\right)$ explains the determination of the optimal portfolio candidates.

The amount of cut-off point $\left(C^{\star}\right)$ is the value of $C_{i}$, where the last $E R B$ value is still greater than the value of $C_{i}$. Based on Table 5, the candidate's portfolio determination can be seen by measuring $E R B i$ value and $C^{\star} 0.00126$ as stock candidates determiners where the stocks, which have ERBi value more than $C^{\star}$ value, can be classified as portfolio candidates stock. Based on the result, there are 4 assets of stocks of portfolio candidates (UNVR CASA, BNLI, UNVR, and HMSP), while the others 6 stocks are not included in portfolio candidates because of the values of $E R B>C^{*}$. According to Partono et al. (2017), there are 8 stocks of candidates in 17 stocks. Investigation of the formation

Table 4. Values of $A_{i}, B_{i}$, and $C_{i}$

Source: Authors' elaboration.

\begin{tabular}{|c|c|c|c|}
\hline Ticker code & $A_{i}$ & $B_{i}$ & $C_{i}$ \\
\hline FREN & -10.2144 & 440.16 & -0.0059 \\
\hline LPKR & -1.62691 & 368.296 & -0.001 \\
\hline PWON & -0.68802 & 448.263 & -0.0004 \\
\hline CASA & 0.70878 & 29.283 & 0.00054 \\
\hline HMSP & 1.612031 & 483.586 & 0.00091 \\
\hline KLBF & 0.06758 & 374.594 & 0.000041 \\
\hline TLKM & -2.01959 & 534.84 & -0.0011 \\
\hline BNLI & 1.366162 & 189.06 & 0.00092 \\
\hline $\mathrm{BBCA}$ & -2.41413 & 538.529 & -0.0013 \\
\hline UNVR & 2.205533 & 468.953 & 0.00126 \\
\hline
\end{tabular}


Table 5. Determination of the candidate of the optimum portfolio, $E R B>C^{*}$

Source: Authors' elaboration.

\begin{tabular}{|c|c|c|c|c|}
\hline Ticker code & $E R B_{i}$ & & $C^{*}$ & Decision \\
\hline CASA & 0.024204 & $>$ & 0.001255 & Portfolio candidate \\
\hline BNLI & 0.007226 & $>$ & 0.001255 & Portfolio candidate \\
\hline UNVR & 0.004703 & $>$ & 0.001255 & Portfolio candidate \\
\hline HMSP & 0.003333 & $>$ & 0.001255 & Portfolio candidate \\
\hline KLBF & 0.00018 & $<$ & 0.001255 & Non-portfolio candidate \\
\hline PWON & -0.00153 & $<$ & 0.001255 & Non-portfolio candidate \\
\hline TLKM & -0.00378 & $<$ & 0.001255 & Non-portfolio candidate \\
\hline LPKR & -0.00442 & $<$ & 0.001255 & Non-portfolio candidate \\
\hline BBCA & -0.00448 & $<$ & 0.001255 & Non-portfolio candidate \\
\hline FREN & -0.02321 & $<$ & 0.001255 & Non-portfolio candidate \\
\hline
\end{tabular}

of a portfolio on several stocks concluded there is 5 stock candidate of 24 selected stocks. These stocks are INDF 2\%, UNVR 30\%, BBTN 9, BBRI 44\%, and TLKM 15\% with an expected return of $3.68 \%$ and a risk of $0.02 \%$. Murthy (2018) researched the Indian stock market by forming a portfolio using the SIM. As many as 14 metal stocks have been selected from the iron and steel industry and these stocks are the constituents of the NSE Nifty metal index from January 2012 to December 2016. The calculation results show that only crane company shares are the optimal portfolios, namely Vedanta and Tata steel with the ideal investment proportion of $86.37 \%$ and $13.62 \%$, respectively.

Calculating the proportions of each stock is an important thing to form a portfolio because stock proportions affect the level of risks and along with total returns that can be gained in the future after the portfolio is formed. In Table 6, the only stock proportion of portfolio candidates will be calculated because these stocks will be selected and formed as option calculation symbolized by $w_{i}$ with a scale of each stock and $z_{i}$ as a component that included $w_{i}$. Based on the weighted average $\left(w_{i}\right)$, the proportion of each share that makes up the portfolio can be determined, namely CASA about 50\%, BNLI 26\%, UNVR 15\%, and HMSP 9\%.

Using formula 4 it can be calculated that the value of the portfolio return is $E\left(R_{p}\right)=\alpha_{p}+\beta_{p} . E\left(R_{m}\right)=$ $0.00193+0.050831(-0.002)=0.00093$ or $0.093 \%$. Based on Table 7, the level of portfolio risk is described by standard deviation having a value of 0.02438 or $2.4 \%$ where this value is greater than the expected return of the portfolio, which means that the portfolio has a fairly high level of risk and it can be seen that the optimal portfolio risk is $0.059 \%$. The risk is much less than the risk of an individual, CASA (0.078\%), BNLI (0.113\%), UNVR (0.203\%), and HMSP $(0.234 \%)$. The calculation of Sharpe index is negative about -1.80739 . The negative value of the SIM indicates that the performance of the portfolio in the COVID-19 period is not good. The greater the value of the portfolio Sharpe ratio, the better the risk-adjusted performance, and a negative Sharpe index value indicates that the portfolio has a bad performance (McLeod \& Van Vuuren, 2004).

Ho2 and Ha2 can be tested by building prepositions where based on previous results and supported by relevant theories the formulated hypothesis can be proved. Following Nurhayati et al. (2021a),

Table 6. $Z_{i}$ and $W_{i}$ of $E R B i$ and $C^{*}$ values

Source: Authors' elaboration.

\begin{tabular}{|c|c|c|c|c|c|c|}
\hline Ticker code & $z_{i}$ & $w_{i}$ & $\alpha \times w_{i}$ & $B \times w_{i}$ & $\sigma_{e i}^{2} \times w_{i}$ & $\%$ \\
\hline CASA & 4.377775 & 0.50315 & -0.00038 & 0.077237 & 0.000405 & 0.50315 \\
\hline BNLI & 2.256717 & 0.259371 & 0.000942 & 0.129739 & 0.000343 & 0.259371 \\
\hline UNVR & 1.319504 & 0.151654 & 0.000848 & 0.185828 & 0.000486 & 0.151654 \\
\hline HMSP & 0.74674 & 0.085825 & 0.000523 & 0.115504 & 0.000321 & 0.085825 \\
\hline Total & 8.700737 & 1 & 0.001933 & 0.508308 & 0.001555 & 1 \\
\hline
\end{tabular}


Table 7. Portfolio risk and portfolio performance

Source: Authors' elaboration.

\begin{tabular}{c|c|c|c|c|c|c}
\hline$\beta_{p}{ }^{2} \cdot \sigma_{m}{ }^{2}$ & $\sum_{i=1}^{n} w_{i}{ }^{2} \cdot \sigma_{e i}{ }^{2}$ & $\sigma_{p}{ }^{2}$ & $\sigma_{p}=\sqrt{\sigma_{p}{ }^{2}}$ & $E\left(R_{p}\right)$ & $R_{f}$ & Sharpe index \\
\hline 0.0002 & 0.00039 & 0.000595 & 0.02438 & 0.000928479 & 0.045 & -1.80739 \\
\hline
\end{tabular}

stock performance evaluation using the Sharpe index, Treynor alpha, and Jensen alpha show that most stocks are underperformed. The COVID-19 pandemic has had a long-lasting effect on the performance of the international financial market. The market has become very volatile and more persistent. Even when compared to the disturbances that occurred before COVID-19, the volatility conditions are higher after the COVID-19. The state of the financial market with a higher and persistent level of volatility should be incorporated into a bet- ter trading strategy to minimize the perceived uncertainty (Vera-Valdés, 2021). The long-term effect on the performance of the international financial market is strongly influenced by perceptions, views, and fears over the existence of the COVID-19. Confidence in the end of the COVID-19 pandemic at the beginning of this pandemic has a positive effect on the rate of return. This should be a concern for investors to be careful in managing their portfolios during the COVID-19 pandemic (Karamti \& Belhassine, 2021).

\section{CONCLUSION}

This study analyzes portfolio formation and evaluates portfolio performance using the SIM method during the COVID-19 on the IDX. The analysis of the best portfolio formation begins by selecting 10 high-capitalization stocks representing five price fractions. The determination of these high-capitalization stocks is assuming that the stocks have high profitability so that they can survive in times of crisis. Empirical results show that of the 10 high-capitalization stocks, there are only 4 stocks that can be chosen in the formation of a stock portfolio as portfolio candidates because based on calculations, they have an excess return to a beta of the security $i(E R B)$ that is higher than the value of the cut-off point $\left(C^{\star}\right)$. The other six stocks were not selected because the $E R B$, value is less than $C^{*}$. The four stocks are CASA, $B N L I, U N V R$, and HMSP with the following proportions for each share as follows: $50 \%$ for CASA, $26 \%$ for $B N L I, 15 \%$ for $U N V R$, and $9 \%$ for HMSP. Finally, Sharpe single index model has a negative value. The negative value of Sharpe ratio indicates that the performance of a portfolio consisting of stocks with high capitalization and representing several tick sizes that have been processed by an optimal portfolio formation was underperforming.

During the COVID-19 pandemic and its outbreaks, although a portfolio has been formed based on an in-depth analysis using the recommended model, the portfolio has not yet given its best performance. This is because as the systematic risk, the pandemic has an impact on the stock performance not only in Indonesia but also throughout the world and no one can escape it. At least an analysis of portfolio formation and evaluation of its performance can minimize even greater losses if it is not carried out with the right analysis. The finding of this study can be recommendations and help for investors by increasing their knowledge and insight on how to make the right investment decisions to earn profits and avoid losses by choosing stocks that have high liquidity with relatively stable prices. Several other methods can be implemented in formation and evaluation portfolio performance besides the Sharpe single index model, such as the Jensen alpha and Treynor model. This paper only uses one model and does not use other models so it cannot be compared. Therefore, in this regard, it is open for further research opportunities to conduct the same study with a different model. 


\section{AUTHOR CONTRIBUTIONS}

Conceptualization: Immas Nurhayati.

Data curation: Renea Shinta Aminda.

Formal analysis: Endri Endri.

Funding acquisition: Titing Suharti, Leny Muniroh.

Investigation: Endri Endri.

Methodology: Immas Nurhayati, Renea Shinta Aminda.

Project administration: Titing Suharti, Leny Muniroh.

Resources: Leny Muniroh.

Software: Immas Nurhayati, Renea Shinta Aminda.

Supervision: Endri Endri, Leny Muniroh.

Validation: Immas Nurhayati, Renea Shinta Aminda.

Visualization: Titing Suharti.

Writing - original draft: Immas Nurhayati, Titing Suharti.

Writing - reviewing \& editing: Endri Endri.

\section{REFERENCES}

1. Al-Awadhi, A. M., Alsaifi, K., Al-Awadhi, A., \& Alhammadi, S. (2020). Death and contagious infectious diseases: Impact of the COVID-19 virus on stock market returns. Journal of Behavioral and Experimental Finance, 27, 100326. https://doi.org/10.1016/j. jbef.2020.100326

2. Alexakis, C., Balios, D., \& Stavraki, S. (2007). A Dynamic approach for the evaluation of portfolio performance under risk conditions. Investment Management and Financial Innovations, 4(4), 16-24. Retrieved from https://www.businessperspectives.org/images/pdf/applications/publishing/templates/article/ assets/1926/imfi_en_2007_04_1_ Alexakis.pdf

3. Ashraf, B. N. (2020). Stock markets' reaction to COVID-19: cases or fatalities? Research in International Business and Finance, 54, 101249. https://doi. org/10.1016/j.ribaf.2020.101249

4. Endri, E., Abidin, Z., Simanjuntak, P. T., \& Nurhayati, I. (2020a). Indonesia Stock Market Volatility: GARCH Model. Montenegrin Journal of Economics, 16(2), 7-17. https://doi.org/10.14254/1800$5845 / 2020.16-2.1$

5. Endri, E., Sulastri, S., Syafarudin, A., Mulayana, B., Imaningsih,
E. S., \& Setiawati, S. (2020b).

Determinant cash holding of coal mining companies listed on the Indonesia Stock Exchange. Academy of Strategic Management Journal, 19(6), 1-9. Retrieved from https://www.abacademies.org/ articles/determinants-cash-holding-of-coal-mining-companieslisted-on-the-indonesian-stockexchange-9802.html

6. Kamil, A. A., \& Wan, K. M. (2004). Extension of Markowitz model for portfolio analysis. WSEAS Transactions on Mathematics, 3(3), 641-646. Retrieved from https:// www.academia.edu/1771214/ Extension_of_Markowitz_Model_ for_Portfolio_Analysis

7. Karamti, C., \& Belhassine, O. (2021). COVID-19 pandemic waves and global financial markets: Evidence from wavelet coherence analysis. Finance Research Letters, 102136. https:// doi.org/10.1016/j.frl.2021.102136

8. Khan, K., Zhao, H., Zhang, H., Yang, H., Shah, M. H., \& Jahanger, A. (2020). The Impact of COVID-19 Pandemic on Stock Markets: An Empirical Analysis of World Major Stock Indices. The Journal of Asian Finance, Economics, and Business, 7(7), 463-474. https://doi.org/10.13106/ jafeb.2020.vol7.no7.463
9. Mahmud, I. (2019). Optimal Portfolio Construction: Application of Sharpe's SingleIndex Model on Dhaka Stock Exchange. JEMA: Jurnal Ilmiah Bidang Akuntansi dan Manajemen, 16(1), 60-92. http://dx.doi. org/10.31106/jema.v16il.1736

10. Marisetty, N. (2012). Construction of Optimal Portfolio using Sharpe Index Model. International Conference on Challenges and opportunities in Mechanical Engineering, Industrial Engineering and Management Studies ICCOMIM-2012. https://doi. org/10.2139/ssrn.3456697

11. Markowitz, H. (1952). Portfolio selection. The Journal of Finance, 7(1), 77-91. https://doi. org/10.2307/2975974

12. Mcleod, W., \& Van Vuuren, G. (2004). Interpreting the Sharpe ratio when excess returns are negative. Investment Analysts Journal, 33(59), 15-20. https://doi org/10.1080/10293523.2004.110 82455

13. Murthy, J. (2018). The construction of optimal portfolio using sharpe's single index model-an empirical study on nifty metal index. JIMS8M: The Journal of Indian Management \& Strategy, 23(4), 4-8. https://doi.org/10.5958/09739343.2018.00026.1 
14. Nurhayati, I., \& Endri, E. (2020). A New Measure of Asset Pricing. Friction-Adjusted Three-Factor Model. The Journal of Asian Finance, Economics, and Business, 7(12), 605-613. https://doi org/10.13106/jafeb.2020.vol7. no12.605

15. Nurhayati, I., Endri, E., Aminda, R. S., \& Muniroh, L. (2021a). Impact of COVID-19 on Performance Evaluation Large Market Capitalization Stocks and Open Innovation. Journal of Open Innovation: Technology, Market, and Complexity, 7(1), 56. https:// doi.org/10.3390/joitmc7010056

16. Nurhayati, I., Suharti, T., Rinda, R T., \& Endri, E. (2021b). Impact of Tick Size Reduction on the Marke Liquidity Using Trading Friction. Academy of Strategic Management Journal, 20(1), 1-11. Retrieved from https://www.abacademies. org/articles/impact-of-tick-sizereduction-on-the-market-liquidity-using-trading-friction-9961. html

17. Partono, T., Widiyanto., Yulianto, A., \& Vidayanto, H. (2017). The Analysis of Optimal Portfolio Forming with Single Index Model on Indonesia Most Trusted Companies. International Research Journal of Finance and Economics, 163, 50-59. Retrieved from http:// www.internationalresearchjournaloffinanceandeconomics.com/ISSUES/IRJFE_163_04.pdf
18. Putra, I. K. A. A., \& Dana, I. M. (2020). Study of Optimal Portfolio Performance Comparison: Single Index Model and Markowitz Model on LQ45 Stocks in Indonesia Stock Exchange. American Journal of Humanities and Social Sciences Research (AJHSSR), 4(12), 237-244. Retrieved from https://www.ajhssr. com/wp-content/uploads/2020/12/ ZE20412237244.pdf

19. Razak, A., Nurfitriana, F. V., Wana, D., Ramli, R., Umar, I., \& Endri, E. (2020). The Effects of Financial Performance on Stock Returns Evidence of Machine and Heavy Equipment Companies in Indonesia. Research in World Economy, 11(6), 131-138. https:// doi.org/10.5430/rwe.v11n6p131

20. Sharpe, W. F. (1963). A Simplified Model for Portfolio Analysis. Management Science, 9(2), 277293. https://doi.org/10.1287/ mnsc.9.2.277

21. Sholehah, N. A., Permadhy, Y. T., \& Yetty, F. (2020). The Comparison of Optimal Portfolio Formation Analysis with Single Index Model and Capital Asset Pricing Model in Making Investment Decision. European Journal of Business \& Management Research, 5(4), 1-9. https://doi. org/10.24018/ejbmr.2020.5.4.470

22. Subashree, S., \& Bhoopal, M. (2017). Construction of Optimal
Portfolio Using Sharpe's Single Index Model: A study with reference to Banking and Automobile sectors. Asia Pacific Journal of Research, 4(2), 74-83.

23. Suryadi, S., Endri, E., \& Yasid, M. (2021). Risk and Return of Islamic and Conventional Indices on the Indonesia Stock Exchange. The Journal of Asian Finance, Economics, and Business, 8(3), 23-30. https://doi.org/10.13106/ jafeb.2021.vol8.no3.0023

24. Suryani, A., \& Herianti, E. (2015). The Analysis of Risk Adjusted Return Portfolio Performance Share for LQ 45 Index in Indonesia Stock Exchange in 2010-2014 Periods. Procedia - Social and Behavioral Sciences, 211, 634-643. https://doi. org/10.1016/j.sbspro.2015.11.087

25. Vera-Valdés, J. E. (2021). The persistence of financial volatility after COVID-19. Finance Research Letters, 102056. https:// doi.org/10.1016/j.frl.2021.102056

26. Zakarias, V., \& Tumewu, F. (2015). Evaluating Portfolio Performance of Companies stock Listed in Lq45 Based on Sharpe, Treynor and Jensen Method. Jurnal Riset Ekonomi, Manajemen, Bisnis Dan Akuntansi, 3(2), 55-64. Retrieved from https://ejournal.unsrat. ac.id/index.php/emba/article/ view/8355 